\title{
Cow's Milk Allergy or Gastroesophageal Reflux Disease-Can We Solve the Dilemma in Infants?
}

\author{
Silvia Salvatore ${ }^{1, *}$, Massimo Agosti ${ }^{1}$, Maria Elisabetta Baldassarre ${ }^{2} \mathbb{D}$, Enza D'Auria ${ }^{3}$, Licia Pensabene ${ }^{4} \mathbb{D}$, \\ Luana Nosetti ${ }^{1}$ and Yvan Vandenplas ${ }^{5}$ iD
}

1 Department of Medicine and Surgery, Pediatric Unit, "F. Del Ponte" Hospital, University of Insubria, 21100 Varese, Italy; massimo.agosti@uninsubria.it (M.A.); luana.nosetti@uninsubria.it (L.N.)

2 Department of Biomedical Sciences and Human Oncology-Neonatology and NICU Section, "Aldo Moro" University of Bari, 70124 Bari, Italy; mariaelisabetta.baldassarre@uniba.it

3 Department of Pediatrics, Vittore Buzzi Children's Hospital, University of Milan, 20154 Milan, Italy; enza.dauria@unimi.it

4 Department of Medical and Surgical Sciences, Pediatric Unit, University “Magna Graecia” of Catanzaro, 88100 Catanzaro, Italy; licia.pensabene@gmail.com

5 Kidz Health Castle, Universitair Ziekenhuis Brussel, Vrije Universiteit Brussel, 1090 Brussels, Belgium; yvan.vandenplas@uzbrussel.be

* Correspondence: silvia.salvatore@uninsubria.it; Tel.: +39-0332-299-247

Citation: Salvatore, S.; Agosti, M.; Baldassarre, M.E.; D'Auria, E.; Pensabene, L.; Nosetti, L.; Vandenplas, Y. Cow's Milk allergy or Gastroesophageal Reflux

Disease-Can We Solve the Dilemma in Infants?. Nutrients 2021, 13, 297. https://doi.org/10.3390/nu13020297

Academic Editor: Sara Manti Received: 24 December 2020

Accepted: 18 January 2021

Published: 21 January 2021

Publisher's Note: MDPI stays neutral with regard to jurisdictional claims in published maps and institutional affiliations.

Copyright: (c) 2021 by the authors. Licensee MDPI, Basel, Switzerland. This article is an open access article distributed under the terms and conditions of the Creative Commons Attribution (CC BY) license (https:/ / creativecommons.org/licenses/by/ $4.0 /)$.

\begin{abstract}
Cow's milk allergy (CMA) and gastro-esophageal reflux disease (GERD) may manifest with similar symptoms in infants making the diagnosis challenging. While immediate reaction to cow's milk protein indicate CMA, regurgitation, vomiting, crying, fussiness, poor appetite, sleep disturbances have been reported in both CMA and GERD and in other conditions such as functional gastrointestinal disorders, eosinophilic esophagitis, anatomic abnormalities, metabolic and neurological diseases. Gastrointestinal manifestations of CMA are often non-IgE mediated and clinical response to cow's milk free diet is not a proof of immune system involvement. Neither for non- $\operatorname{IgE}$ CMA nor for GERD there is a specific symptom or diagnostic test. Oral food challenge, esophageal $\mathrm{pH}$ impedance and endoscopy are recommended investigations for a correct clinical classification but they are not always feasible in all infants. As a consequence of the diagnostic difficulty, both overand under- diagnosis of CMA or GERD may occur. Quite frequently acid inhibitors are empirically started. The aim of this review is to critically update the current knowledge of both conditions during infancy. A practical stepwise approach is proposed to help health care providers to manage infants presenting with persistent regurgitation, vomiting, crying or distress and to solve the clinical dilemma between GERD or CMA.
\end{abstract}

Keywords: reflux; GER; GERD; cow's milk allergy; CMA; eosinophilic esophagitis; infants; hydrolyzed formula; alginate; thickened formula

\section{Introduction}

Gastroesophageal reflux (GER) and cow milk allergy (CMA) occur frequently in the first year of life [1-4]. The pathogenesis of these two conditions is complex and involves multiple mechanisms of nutrition, motility, immunology and hypersensitivity. A number of papers discussed the overlapping symptoms or simultaneous occurrence of CMA and GERD [1,4-29] Nonetheless, discrimination between both disorders is still challenging due to the similarity of the symptoms and the lack of accurate and handy diagnostic tests [1,27]). Although the response to a CM elimination diet and oral challenge are essential to confirm the diagnosis of CMA [30-33], a positive challenge test does not proof the involvement of the immune system. Moreover, delayed reactions as occurring in non-IgE mediated allergy, may be insufficiently recognized with an oral challenge test. Upper endoscopy and biopsies and esophageal $\mathrm{pH}$-impedance are the recommended diagnostic investigations for GERD [34]. However, a normal endoscopy and histology does not rule out GERD, 
as is the case in non-erosive GERD. Normal ranges for $\mathrm{pH}$-impedance are missing and parameters such as symptom association probability have not been validated in children. Performance of $\mathrm{pH}$-impedance is also hampered by cost and investment of time [34,35]. As a consequence, under- or over-diagnosis of CMA and GERD are likely to occur. CM protein elimination diet and treatment with acid inhibitors are often empirically initiated and are, sometimes, excessively protracted.

The aim of this review is to critically update the current knowledge of both conditions during infancy and to provide clinicians a practical stepwise diagnostic and therapeutic approach for infants presenting with persistent regurgitation, vomiting, crying or distress.

\section{CMA and GERD: A Pathogenic Twist}

GER and other persistent gastrointestinal symptoms in allergic patients are predominantly associated with cellular immune mechanisms and delayed reactions. In non-IgE mediated CMA, activated mast-cells, eosinophils and Th2 lymphocytes, release histamine, tryptase, IL-4, IL-5, IL-13, eotaxin and other chemokines that lead to increased permeability, epithelial dysfunction, inflammatory infiltration in the mucosal, submucosal and, in some cases, muscle layers and nociception $[25,27,28,36]$.

A migration of activated mast cells in proximity of enteric nervous system has been demonstrated in allergic children exposed to $\mathrm{CM}$ proteins and may determine gastrointestinal dysmotility and related symptoms [37].

GER and regurgitation are commonly related to overfeeding, short length of the (intraabdominal) esophagus, obtuse His angle, horizontal position of the infant. Inappropriate relaxations of the lower esophageal sphincter (LES), ineffective clearance and the impaired resistance of the esophageal mucosa contribute to GERD [34].

Crying and pain in infants and children are determined by interplaying factors such as esophageal and gastrointestinal distension, dysmotility, visceral hyperalgesia, genetics, early life events, inflammatory and microbiota components, increased permeability, stress, parental and individual coping and perception $[4,38,39]$.

GER and CMA can coexist in the same patient and it has been reported that CMA can induce GER and also be a predisposing factor for gastrointestinal functional disorders [22,27]. Conversely, treatment with acid inhibitors for GERD increase the risk of allergy later in life $[40,41]$.

\section{Functional Disorder, CMA or GERD: The Clinical Enigma}

\subsection{Definition and Epidemiological Data of Infant Regurgitation and Colic}

Infant regurgitation and colic are defined by the Rome IV criteria as functional gastrointestinal disorders (FGIDs) of infancy [42]. Diagnostic criteria for infant regurgitation must include at least due episodes of regurgitation per day for at least three weeks in an otherwise healthy infant 3 weeks to 12 months of age without retching, hematemesis, aspiration, apnea, failure to thrive, feeding or swallowing difficulties or abnormal posturing [42]. Infant colic is defined by recurrent or prolonged periods of crying, fussing or irritability that occur without an obvious cause, that cannot be prevented or resolved by caregivers in an infant younger than 5 months with no failure to thrive, fever or illness [42]. For clinical research purposes, to fulfill the definition of colic these episodes of crying or fussiness should last at least $3 \mathrm{~h}$ per days, for a minimum of one day when measured by a prospectively kept $24 \mathrm{~h}$ behavior diary or 3 days per week according to a caregiver's interview [42]. They affect, alone or in combination and depending on selection and inclusion criteria around 20 to $25 \%$ of infants all over the world $[4,39,43,44]$. Neonates born preterm, small for gestational age or exposed to early life antibiotics have been recently reported to be at increased risk of infantile regurgitation and colic [45,46]. One fifth to one third of parents are concerned about their infant's health condition and consult health care providers because of regurgitation, fussiness and crying [3,4,39,41,47]. Regurgitation and infantile colic occur mostly during the first three to four months of life, with a natural resolution in the vast majority of cases around 4 to 5 months for colic and from 6 months 
onwards for regurgitation [3,42,48-50]. When the onset of regurgitation is in the first two weeks of life or when projectile vomiting is the predominant symptom, secondary GER related to anatomic malformations or conditions such as CMA are more likely [42].

\subsection{Symptoms and Prevalence of GERD in Infants}

When GER is associated with troublesome, persistent severe symptoms or complications (e.g., respiratory problems or esophagitis) it is referred to as GERD [34]. As the definition of troublesome is subjective, the distinction between GER and GERD is challenging in infants and the two terms are often misused interchangeably [34].

The most frequently reported symptom of GER in infants is regurgitation but the latter is neither sensitive nor specific to diagnose GERD, neither if associated with crying or fussiness $[14,15,34,38,47,51-53]$. Thus, acid inhibitors should not be started in these infants unless an investigation-based diagnosis of GERD is established [34]. The exact prevalence of GERD in infants is difficult to define because symptoms are not specific, empirical treatment is often started, many infants are not submitted to $\mathrm{pH}$-impedance and/or endoscopy and prospective data are limited. The only report in which healthy infants $(\mathrm{N}=509)$, screened for risk of sudden infant death syndrome, underwent $\mathrm{pH}$-monitoring dates from 1991 [54]. Using a glass microelectrode to detect acid $\mathrm{pH}$, the 95th percentile of esophageal acid exposure rate, during the first 12 months of life, was about $10 \%$ [54]. Hence, $5 \%$ of healthy infants, would present a pathological oesophageal acid exposure when the threshold is fixed to $10 \%$. In the last 30 years, for ethical reasons, only symptomatic infants suspected to have GERD were investigated. When 151 infants with persistent crying underwent $\mathrm{pH}-$ monitoring, $17.9 \%$ infants had pathological acid exposure time $(>10 \%)$ and no association with total crying duration was noted [15]. Regurgitation occurring more than 5 times daily was the most specific GERD symptom (specificity $70.9 \%$ ) but had a poor positive predictive value $(22 \%)$. In the absence of frequent regurgitation or feeding difficulties, pathological GERD according to $\mathrm{pH}$ monitoring results was unlikely (negative predictive value 87-90\%) [15]. In another study evaluating 100 infants, suspected of having GERD, a pathological $\mathrm{pH}$ tracing was found in $21 \%$ of cases and esophagitis was identified in 17 out of 44 infants (39\%) underwent endoscopy, with poor correlation between clinical symptoms, histology and $\mathrm{pH}$ results [51]. In a multicenter retrospective cross-sectional study in the United States using an Endoscopy Database System, emerged that 5.5\% of children aged 0 to 1 year had erosive esophagitis [55]. In another cohort of 245 infants with symptoms of reflux submitted to endoscopy and esophageal biopsy, 62 cases (25\%) had histological esophagitis [56]. In 8 out of 40 infants (20\%) referred for persisting symptoms attributed to GERD (regurgitation and/or vomiting and inconsolable crying, fussiness, irritability, sleeping difficulties or respiratory problems for at least 2 weeks, in the absence of any other identifiable cause) a pathological acid exposure (defined as $\geq 7 \%$, as measured by an antimony electrode) was found by $\mathrm{pH}$-impedance [57]. More recently, our group analyzed impedance-pH tracings of 62 children (ages 15 days to 23 months, median age 3.5 months) with persistent unexplained fussiness or distress and $19 \%$ showed an acid reflux exposure time $>7 \%$ [58].

\subsection{Symptoms and Prevalence of CMA in Infants}

The prevalence of hospital based diagnosed CMA in the first year of life ranges from $0.5 \%$ to $3 \%$ of infants, with the lowest rate when breast feeding and food challenge are considered [25,28,36,59]. Nonetheless, in a Finnish study, of the 824 exclusively breast-fed infants, $2.1 \%$ had CMA, verified by a CM elimination-challenge test [60].

In the EuroPrevall birth cohort study, 12,049 children with symptoms possibly related to CMA were enrolled and $77.5 \%$ were followed up to 2 years of age. Clinical evaluation included CM-specific IgE antibodies (IgE), skin prick test and double-blind, placebocontrolled food challenge. CMA was suspected in $358(3 \%)$ children and confirmed by the food challenge in 55 cases $(0.54 \%, 95 \%$ CI 0.41-0.70). Of all children with CMA, 23.6\% 
had negative specific serum IgE and all of them tolerated CM one year after diagnosis compared to $57 \%$ of those children with IgE-associated CMA [59].

According to these epidemiological data, the expected casual coexistence of CMA and GERD would occur, by far, in less than $1 \%$ of the breastfed or formula fed infants. In breastfed infants, reflux and infantile colic as single manifestations are only seldom caused by CMA [61].

GERD may be the cause of regurgitation, vomiting, feeding disorders, day and night crying [34]. Similar symptoms may also be present in CMA and make it difficult to understand which condition is responsible for the clinical picture, especially in the absence of other signs of allergy, such as atopic dermatitis or otherwise unexplained rectal bleeding in the first months of life $[1,4,30,31,61,62]$.

Prolonged crying during or after a meal or in the evening and night are often erroneously attributed to both CMA and GERD which seem to be responsible for only $5-10 \%$ of cases of infantile colic [25,27,38].

Repeated episodes of incoercible vomiting, with possible severe dehydration, lethargy and diarrhea occurring within a few hours from CM intake, can be classified as food protein induced enterocolitis syndrome (FPIES) [63,64]. Diarrhea, poor feeding, vomiting, failure to thrive and malabsorption are reported in food protein enteropathy. Food protein induced allergic proctocolitis typically shows he presence of blood and mucous in the stools and mild diarrhea in otherwise well-appearing, often breastfed infants [28,31-33,64].

\subsection{Literature Data on the Association of CMA and GERD}

A number of studies examined the presence of CMA in infants with symptoms attributed to GERD (Table 1).

Table 1. Summary of the studies evaluating the association of cow's milk allergy (CMA) and gastro-esophageal reflux disease (GERD) (modified from Ferreira 2014 [23]).

\begin{tabular}{|c|c|c|c|}
\hline Author, Year & Population & Investigation & Main Results \\
\hline Forget, 1985 [5] & $\begin{array}{l}15 \text { children with recurrent } \\
\text { vomiting }\end{array}$ & $\begin{array}{c}\text { Contrast } \mathrm{X} \text {-ray, small bowel } \\
\text { biopsy }\end{array}$ & $\begin{array}{l}\text { All children showed GER on X-ray. } \\
3 / 15(20 \%) \text { had enteropathy with IgE } \\
\text { plasmatocytes, reported no } \\
\text { improvement with GER treatment but } \\
\text { disappearance on symptoms on CM } \\
\text { free diet }\end{array}$ \\
\hline McLain, 1994 [6] & $\begin{array}{l}10 \text { infants with GERD who } \\
\text { failed to respond to reflux } \\
\text { treatment }\end{array}$ & pH-monitoring & $\begin{array}{l}\text { Symptoms improved in } 2 / 10(20 \%) \\
\text { infants on CM free diet. No infant } \\
\text { showed significant improvement in pH } \\
\text { monitoring indices }\end{array}$ \\
\hline Staiano, 1995 [11] & $\begin{array}{l}25 \text { infants with recurrent } \\
\text { vomiting }\end{array}$ & $\begin{array}{l}\text { Endoscopy and small bowel } \\
\text { biopsies, permeability test }\end{array}$ & $\begin{array}{c}\text { Primary GERD in 16/25 (64\%), GERD + } \\
\text { CMA in 4/25 (16\%), CMA alone in } \\
4 / 25(16 \%) \text {. } \\
\text { Enteropathy in 19\% GERD, 67\% CMA. } \\
\text { Abnormal permeability test in 6\% } \\
\text { GERD, } 100 \% \text { CMA }\end{array}$ \\
\hline Iacono, 1996 [9] & $\begin{array}{l}204 \text { infants (median age, } \\
6.3 \text { months) with GERD }\end{array}$ & $\begin{array}{c}\text { pH-monitoring, upper } \\
\text { endoscopy, allergy tests, CM } \\
\text { challenge }\end{array}$ & $\begin{array}{c}93(45 \%) \text { had positive allergy tests, } 85 \\
(42 \%) \text { improved with hydrolyzed } \\
\text { formula and reappeared on challenge. } \\
\text { GER + CMA significantly associated } \\
\text { with the presence of diarrhea or atopic } \\
\text { dermatitis }\end{array}$ \\
\hline
\end{tabular}


Table 1. Cont.

\begin{tabular}{ccc}
\hline Author, Year & Population & Investigation \\
\hline Cavataio, $1996[8]$ & 96 infants with suspected & $\begin{array}{c}\text { Serum specific IgE and IgG, } \\
\text { blood eosinophils, } \\
\text { GH-monitoring, endoscopy, } \\
\text { CM challenge }\end{array}$
\end{tabular}

14 out of $47(30 \%)$ infants with GERD had CMA These infants had similar symptoms to those with primary GERD but significantly higher concentrations of total IgE, circulating eosinophils and IgG anti-beta lactoglobulin. A specific phasic $\mathrm{pH}$ pattern, with progressive decrease in $\mathrm{pH}$ tracing, occurred in 24/25 infants with CMA, 12/14 GERD $+\mathrm{CMA}$ and 0 controls. CM free diet improved only in the ones with CMA

Milocco, 1997 [10] 112 infants with GERD $\quad$ pH-monitoring, CM challenge

19 infants with persistent

Hill, 2000 [14] distress and GER symptoms with no response to eHF and GERD treatment

Endoscopy, pH-monitoring, $\mathrm{CM}$ challenge
18 infants (16\%) had CMA, 10/18 had failure to thrive. A phasic $\mathrm{pH}$-pattern was present in $1 / 18$ with CMA and in 3 with only GERD

Nine infants had histologic evidence of esophagitis and 9 had inflammatory changes in the stomach and/or duodenum. Symptoms remitted in all infants within 2 weeks of starting AAF. On double blind challenge, after a median period of 3 months of AAF, 12 infants were still intolerant to $\mathrm{CM}$

Children with CMA showed more gastric dysrythmia ( $67 \%$ vs. $29.4 \%$ GER and $30.4 \%$ controls) and delayed gastric emptying ( $89 \pm 26 \mathrm{~min})$ compared to infants with GERD ( $54 \pm 13 \mathrm{~min})$ and controls (62 $\pm 13 \mathrm{~min}$ ). 7/7 CMA patients had regurgitation and/or vomiting, colic and positive family history of allergy

All infants with a clinical diagnosis for GER showed delayed gastric emptying vs. normal subjects

Ultrasonography to measure gastric emptying time-with CM formula and protein hydrolysate

(205 vs. $124 \mathrm{~min}, p=0.000$ ).

With eHF there was a significant improvement in gastric emptying time and symptoms especially in infants with positive skin-test and RAST

$10(56 \%)$ infants had CMA + GERD (higher acid exposure time vs. primary GERD), responded to $\mathrm{CM}$ free diet and had a positive challenge which was not associated with a significant increase in the esophageal acid exposure in the simultaneous $\mathrm{pH}$ monitoring

17 infants and children (aged

Nielsen, 2006 [18]

\section{2-178 months) (mean age of} 7.8 years) with GERD
Endoscopy and biopsies, $\mathrm{pH}$-monitoring, allergy tests, $\mathrm{CM}$ challenge
Endoscopy, 48-h pH-metry

(Day 1-elimination diet, Day challenge
10/17 (59\%) were classified as

\section{CMA-GERD.}

Two patients showed $>15$ eosinophils at biopsies (=EoE) No differences in the number of eosinophils, mast cells or $\mathrm{T}$ cells were found between children with CMA and those with primary GERD 
Table 1. Cont.

\begin{tabular}{|c|c|c|}
\hline Author, Year & Population & Investigation \\
\hline $\begin{array}{l}\text { Semeniuk, } 2007 \text { [19] } \\
\text { and 2008 [20] }\end{array}$ & $\begin{array}{c}264 \text { children with suspected } \\
\text { GERD (mean age } \\
21 \pm 17 \text { months) or CMA }\end{array}$ & $\begin{array}{l}\text { Esophageal manometry, } \\
\text { pH-monitoring, allergy tests } \\
\text { and CM challenge }\end{array}$ \\
\hline $\begin{array}{l}\text { Farahmand, } \\
2011 \text { [13] }\end{array}$ & $\begin{array}{l}81 \text { children (aged } 1 \mathrm{mo}-2 \text { yrs, } \\
\text { median } 12.5 \mathrm{mo} \text { ) with } \\
\text { supsected GERD. }\end{array}$ & Clinical study \\
\hline Borrelli, 2012 [22] & $\begin{array}{l}17 \text { children (median age: } \\
14 \text { months) with proven } \mathrm{f} \\
\text { CMA and suspected GERD }\end{array}$ & $\begin{array}{l}\text { 48-h pH-impedance. Day } \\
\text { 1-amino acid formula Day } \\
\text { 2-challenge with cow's milk }\end{array}$ \\
\hline
\end{tabular}

138 children with GERD: 76 only GERD, 62 (23.5\%) GER + CMA/FA 32 only CMA/FA.

No differences between primary GERD and GERD+ CMA in reflux parameters, in the mean values of resting LES pressure and LES length at baseline and during 2 years of follow-up

54 (66\%) responded to PPI, 27 (33\%) to $\mathrm{CM}$ elimination diet

The total reflux episodes and the number of weakly acidic episodes were higher during CM challenge compared with the amino acid-based formula period. No differences were found for either acid or weakly alkaline reflux

Regurgitation was reduced in all infants (from $6.4 \pm 3.2$ to $2.8 \pm 2.9$, $p<0.001)$ but fell more with the thickened hydrolyzed formula $(-4.2 \pm 3.2$ regurgitations/day) vs. non thickened formula, especially in infants with a negative challenge

Vandenplas, $\quad 72$ Infants with suspected 2014 [24] CMA
Clinical study comparing a thickened and non-thickened eHF casein formula: results after one month.

$(-3.9 \pm 4.0$ vs. $-1.9 \pm 3.4, \mathrm{~ns})$. In the group with positive challenge the two formulas showed a similar decrease $(-4.4 \pm 2.6$ vs. $4.7 \pm 5.6)$. The global reduction of a symptom-based score was -7.4 points and the non-thickened hydrolysate was more effective in the group with a positive challenge ( -9.2 vs. -5.7 points)

58 children $(38.4 \%$ ) had positive $\mathrm{CM}$ challenge and $28(48 \%)$ of them had positive skin prck tests or IgE, $16(28 \%)$ had positive patch tests. Bloody stools, atopic dermatitis and recurrent

151 children (aged 3-60 mo) skin prick test, specific serum with GERD resistant to $8 \mathrm{wks}$ PPI treatment patch test and $\mathrm{CM}$ challenge
IgE, eosinophil count, atopy
50 infants with persistent

Omari, 2020 [29] crying, vomiting and/or food refusal (suspected to be GERD and or CMA related)
48 h cry-fuss chart, I-GERQ-R, allergy tests, blinded milk elimination-challenge sequence, $\mathrm{pH}$-impedance before and after $\mathrm{CM}$

elimination, ${ }^{13} \mathrm{C}$-octanoate breath test for gastric emptying, dual-sugar intestinal permeability, fecal calprotectin wheezing episodes were significantly more common in these children Vomiting and diarrhea were more common in non-IgE children. Ten children who had positive challenge were finally diagnosed as EoE

$14(28 \%)$ were diagnosed as non-IgE-mediated CMA, 17 (34\%) had negative challenge, 19 were excluded for equivocal findings or incomplete data. No baseline differences in any of the tests or GERD parameters between infants with and without CMA. In the CMA group, CM elimination significantly reduced reflux symptoms, esophageal acid exposure, acid clearance time and increased impedance baseline 
The association of CMA-GERD was reported in 16-56\% of cases with persistent gastrointestinal symptoms and suspicion of GERD, irrespective of breast or formula feeding $[1,17,23,27-29,45,62]$. The percentage of infants with persistent GER symptoms with clinical improvement on diet and worsening on challenge is extremely variable depending on the population recruited, design of the study and follow up data [27]. In one study, out of 19 infants with persistent distress and GER symptoms with no response to eHF and acid suppressive agents, 9 infants had esophagitis, 9 had inflammatory changes in the stomach and/or duodenum and all 19 improved on amino acid-based formula [14].

\section{The Stepwise Approach to Infants with Regurgitation, Vomiting and Crying}

In each infant, alarm signals indicative of other conditions such as infectious, neurological, anatomic, surgical, genetic or metabolic pathologies should be excluded throughout an accurate medical history and full physical examination (Figure 1).

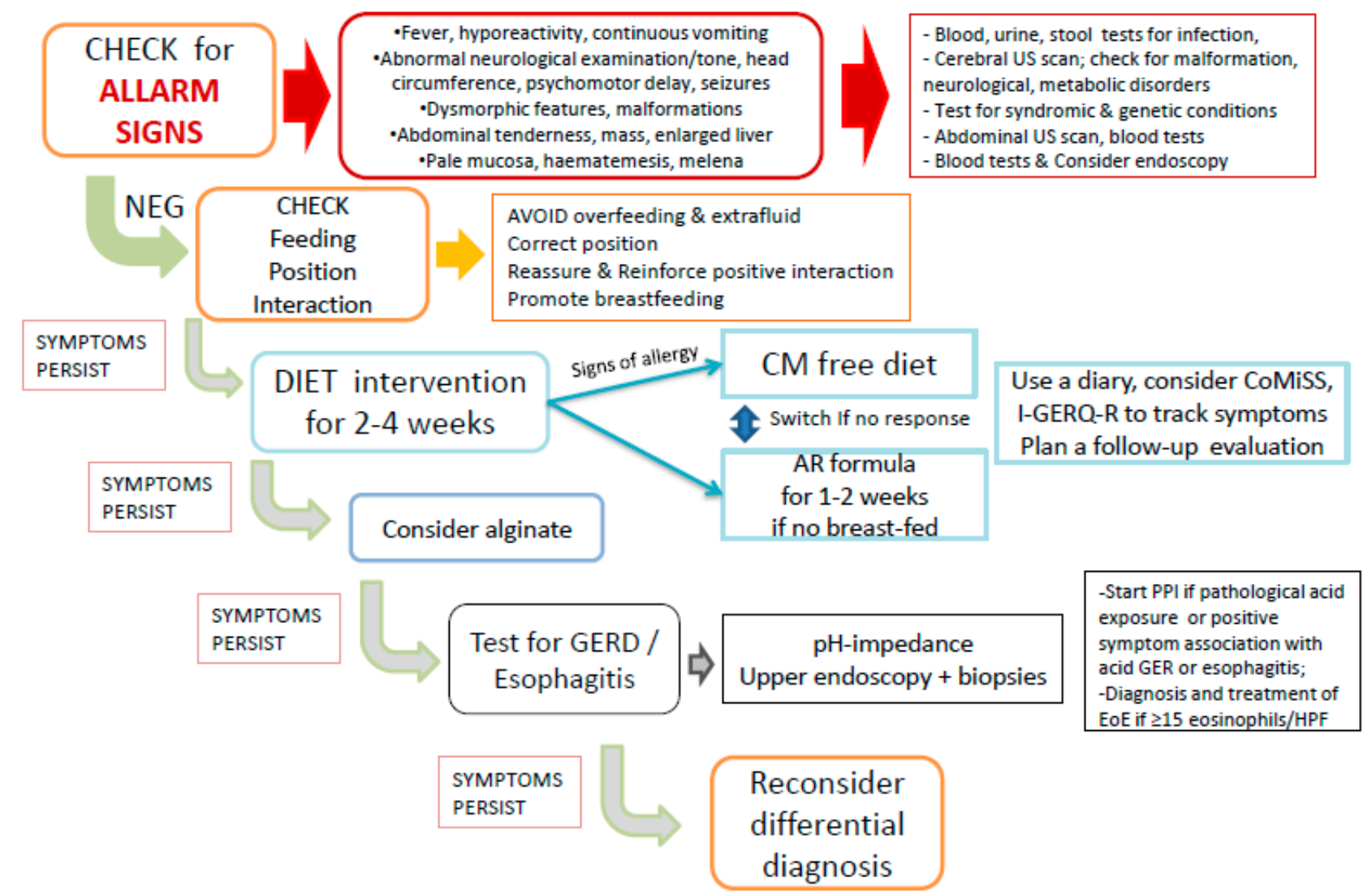

Figure 1. Simplified stepwise approach and ACTION PLAN for infants with persistent ( $\geq 1$ week) regurgitation, vomiting and crying. See text for complete explanation and further details. Legend: US = ultrasound; $C M=$ cow's milk protein; $\mathrm{AR}=$ thickened; $\mathrm{PPI}=$ proton pump inhibitors; GER = gastroesophageal reflux; EoE = eosinophilic esophagitis; $\mathrm{HPF}=$ high power field.

Onset of symptoms in the first week or beyond six months of life is not typical of GER. The presence of seizure, psychomotor delay, lethargy or hyporeactivity, abnormal head circumference, abnormal posturing, prolonged inconsolable crying/irritability, muscle hypo/hypertonia or impaired reflexes should alert for neurological or neuromotor or metabolic diseases. Fever, recurrent infections, prolonged apneas, recurrent brief resolved unexplained events (BRUE) or apparent life-threatening events (ALTE), jaundice, pallor, dehydration, bulging or depressed fontanelle, cyanosis, gastrointestinal bleeding, bilious vomiting, abdominal mass or tenderness, hepato/splenomegaly, multiple bruising or hematomas, weight loss or severe failure to thrive should be promptly investigated [34,65]. 
Abnormal growth, malformations and dysmorphic features should be considered for syndromes and genetic disorders.

Differential diagnosis and specific investigations for these different diseases will not be discussed in this review.

\subsection{Management of CMA and GER in Infants}

In the absence of warning signs, the first step in the management of infants presenting with infantile colic and regurgitation fulfilling the Rome IV criteria is to avoid overfeeding by checking infant's growth and feeding modalities regarding frequency and duration of feeding and preparation and volume in formula-fed infants. Parental education and information on their infant's symptoms mechanisms and evolution are of outmost importance $[4,34,39]$. Reassurance and positive interaction between parents and babies need empathy and patience and should be reinforced [39,65-67].

\subsection{Nutrition, Dietary Modification and Diagnosis of CMA in Infants}

Breastfeeding should always be promoted and continued in all infants, even in CMA, functional gastrointestinal disorders and GERD, as human milk represents the best nutritional option. In formula-fed infants, feeding volume and frequency should be progressively adapted according to age and weight and formula changing should be considered in cases with persistent (distressing) symptoms and/or poor weight gain. Commercial thickened formulas provide controlled concentration of various (locust bean gum/carob flour, tapioca, potato, rice, corn starch) thickening agents and nutritional requirements and is likely to decrease the daily episodes of regurgitation by half [66] within the first week.

The National Institute for Health and Care Excellence (NICE) GER- guidelines suggest a greater likelihood of CMA in the presence of regurgitation associated with chronic diarrhea or blood in the stool, other atopic manifestations (eczema) or a positive family history of allergy. In the ESPGHAN guidelines [30,34] the involvement of symptoms in different organ systems in association with the regurgitation increases the likelihood of CMA. Both regurgitation and atopic dermatitis are common disorders in the first months of life and their relation (overlapping age, coincidence or comorbidity) still needs to be further clarified, especially in infants with severe eczema.

Nonetheless, skin prick tests and specific IgE dosage are positive in only a minority of patients with gastrointestinal symptoms $[1,28]$. Atopy patch tests and the dosage of specific IgG antibodies are not well standardized and thus not recommended for diagnosing CMA $[27,30,31,33]$. As a consequence, elimination of CM proteins during 2 to 4 weeks is the recommended approach $[30,34]$.

In breastfed infants, maternal CM free diet can be considered if symptoms are severe enough. In non-breastfed infants with CMA, formulas with CM based extensively hydrolyzed proteins is indicated as first choice, rice hydrolysates are second options and amino acid based formulas (AAF) should be reserved for more severe clinical reactions $[28,30-33,68]$. Soy infant formula could be considered in some cases, particularly in infants older than six months and in the absence of severe IgE mediated reactions (e.g., anaphylaxis) and gastrointestinal symptoms [31]. Other milk substitutes (from other mammalian species or plant-based beverages) are not recommended because of possible crossreactivity, limited studies and scarce evidence of efficacy and nutritional adequacy [69]. Noteworthy, hydrolyzed formulas may vary considerable in terms of source of proteins, method and degree of hydrolysis, macro and micronutrients, additional components (i.e., pre- and probiotics) and proof of clinical benefit [70]. Thus, the results of one particular formula cannot be transferred to a "new" or "similar" one.

In one study, the effect of a thickened and non-thickened casein extensive hydrolyzed formula was analyzed in 72 formula-fed infants (younger than 6 months) with suspected CMA (including persistent unexplained distress or colic, respiratory and/or dermatological symptoms, diarrhea or constipation or blood in the stools and troublesome regurgitation/vomiting of more than five episodes a day) with no previous anaphylactic 
reactions [24]. The challenge was performed in 52/72 (72\%) of the enrolled population and was positive in $65.4 \%$. All cases tolerated both study-formulas and regurgitation was reduced in all infants $(6.4 \pm 3.2-2.8 \pm 2.9, p<0.001)$. The thickened hydrolysate showed a higher reduction of episodes of regurgitation $(-4.2 \pm 3.2$ regurgitations/day) in infants with both a positive and a negative $(-3.9 \pm 4.0$ regurgitations/day) $\mathrm{CM}$ challenge after one month of treatment compared to a minimal effect of the non-thickened hydrolysate $(-1.9 \pm 3.4$ episode of regurgitation) in the group with a negative challenge [24]. The global reduction of a symptom-based score (assessing crying time, number and volume of episodes of regurgitation, consistency of stools, presence and severity of respiratory and dermatological symptoms unrelated to infections), was -7.4 points, with the highest efficacy for the non-thickened hydrolysate in the group with a positive challenge compared to the negative challenge ( -9.2 vs. -5.7 points) and versus the thickened formulas between the two groups ( -8.1 and -7.1 points) [24]. To better target and assess the effect of a CM free diet, based also on the previous study, a Cow's Milk Related symptom score (CoMiSS) has been proposed as an "awareness tool" for CMA [71]. This is based on scoring daily duration of crying, number and volume of regurgitation episodes, stool pattern, presence and severity of cutaneous and respiratory manifestations, unrelated to infections. The score ranges from 0 to 33 points [71]. A pooled analysis showed that infants with a CoMiSS $>12$ had a $75 \%$ chance to have a positive challenge test [72] and a $89 \%$ probability to respond to $\mathrm{CM}$ free diet according to another report [73]. In a presumed healthy population of infants, the P95 of the CoMiSS was >9 [73,74]. Despite CoMiSS is an easy tool to help identifying infants who can benefit from CM free diet, it does not replace the need for a diagnostic challenge and still requires further validation studies.

The importance of a clinical re-evaluation after a 2-4 weeks is emphasized both to evaluate the clinical benefit and programming the oral challenge in infants who improved or consider other diagnostic steps for the non-responders (Figure 1). The oral challenge test is required for diagnostic confirmation of $\mathrm{CMA}$, proving a reaction to $\mathrm{CM}$ proteins after a clinical response to the exclusion diet [31-33,36]. Given the common acquisition of tolerance in the first year of life, particularly in infants with non-IgE allergy [59], diet re-evaluation and reintroduction of CM proteins should be considered and scheduled in order not to prolong unnecessary dietary restrictions. Supervised CM protein challenges are required; hospital setting and time frame, (after 2, 6 or 12 months of diet) should depend on the clinical scenario [30], including symptoms at onset and results of allergic tests $[28,31-33,36]$.

The role of food allergy and the benefit of CM free diet in persistent unexplained crying classified as infantile colic are still controversial [3,25,75-77]. In an early small trial enrolling 21 colicky infants, CM free diet was superior to parental education and counseling [78]. In another study, enrolling 267 colicky babies, a partially hydrolyzed whey-based formula, containing fructo- and galacto-oligosaccharides and reduced lactose, showed a significant decrease in crying episodes compared to a standard formula after two weeks [79]. In 2010 a systematic review did not report evidence of diet efficacy in colicky infants and highlighted that in most studies data on the reintroduction of normal protein were lacking [75]. However, in 2012, another systematic review analyzed the eleven randomized controlled trials considered to be of good quality and concluded that both breast-fed and formula-fed colicky infants benefited from CM elimination diet [76]. According to the 2018 Cochrane review on dietary modification for infantile colic, including 15 randomized controlled trials and 1121 infants (aged 2 to 16 weeks), a greater reduction in crying time in the intervention group compared to normal CM protein intake was noted in $25 \%$ of infants with moderate or severe symptoms in many but not all studies [77]. However, the available studies had small sample sizes and most had a significant risk of bias [77].

Furthermore, symptoms such as vomiting, regurgitation and crying can decrease and disappear because of the natural evolution or a placebo effect. Nonetheless, symptoms may reappear when a formula with whole proteins (and normal lactose content) is reintroduced 
for mechanisms other than the immunological ones of allergy, such as the facilitating effect of gastric emptying of the (partial and extensively) hydrolyzed proteins or less fermentation in the case of a formula with reduced lactose $[1,4,27]$. Bradigastria and tachigastria have been more frequently detected in patients with CMA than in patients with GER or healthy children [21]. In allergic patients, dysrhythmia, mainly determined by an interaction between eosinophils, mast cells and nerve fibers [37], can impair gastric emptying causing vomiting, increasing reflux and possible pain.

\subsection{Diagnosis and Treatment of GER and GERD}

In both breast-fed and formula-fed infants with persistent regurgitation and distress, aluminum free alginate-based formulations have been reported to significantly reduce the number of episodes of GER and regurgitation and associated symptoms [57,67], with no adverse effects reported in short term trials.

No symptom or cluster of symptoms or questionnaire showed a high sensitivity and specificity for GERD in infants and young children [34,51]. The revised infant GER questionnaire (I-GERQ-R) has a controversial diagnostic value for GERD $[29,51,80]$ but it provides a validated tool to monitor the evolution of symptoms during an intervention trial [80].

The infants who continue to present inconsolable crying and distress, with insufficient improvement after parental reassurance, behavioral and dietetic approaches should be submitted to investigations to identify GERD [34,65].

In some children with GER due to CMA, a particular $\mathrm{pH}$-metric esophageal pattern with a gradual drop in $\mathrm{pH}$ after the meal was noted [8]. However, this finding is not present in all infants who respond to the diet and has not been confirmed by other authors [10]. The $\mathrm{pH}$-impedance analysis showed that patients with CMA have predominantly a non-acid GER component [22] that can be even more painful than acid GER [58] but do not benefit from therapy with acid inhibitors.

Several clinical trials, two systematic reviews [47,81], one meta-analysis [82] and pediatric guidelines on GERD $[34,83]$ have shown that treatment with acid inhibitors is not significantly effective in infants with regurgitation or vomiting and/or protracted crying without instrumental evidence of GERD. However, proton pump inhibitors are often empirically prescribed [84] while should be reserved to infants with pathological acid exposure time or significant temporal association between symptoms and acid GER during pH-impedance [34,35] or with evidence of esophagitis [34].

Upper endoscopy is indicated for cases with persistent crying, vomiting, anemia, feeding problems and failure to thrive to identify and characterize esophagitis or enteropathy. Quantification of eosinophils in esophageal biopsies help to differentiate GERD from eosinophilic esophagitis. The presence of villous atrophy and inflammatory infiltrate in the lamina propria on duodenal biopsies is characteristic of patients with CMA [11]. Intestinal permeability tests are also abnormal in these patients [11] but they are not performed in many hospitals, are non-specific and are of limited sensitivity for cases without enteropathy. Contrast X-ray is useful to detect anatomical abnormalities but has no role in diagnosis of GERD [34]. Video fluoroscopy and laryngeal examination by ENT pediatric specialist may identify abnormal swallowing and malformation determining respiratory manifestations. Nevertheless, the presence of laryngeal edema and hyperemia has a limited correlation with $\mathrm{pH}$-impedance results in infants and children [85].

In a recent study 50 infants with persisting crying, vomiting and/or food refusal attributed to CMA and/or GERD were extensively investigated including atopy patch test for $\mathrm{CM}$, milk specific serum IgE antibodies, $48 \mathrm{~h}$ cry-fuss diary, I-GERQ-R questionnaire, blinded milk elimination-challenge sequence, $24 \mathrm{~h} \mathrm{pH}$-impedance monitoring before and after $\mathrm{CM}$ elimination, ${ }^{13} \mathrm{C}$-octanoate breath testing for gastric emptying, dual-sugar intestinal permeability, fecal calprotectin and serum vitamin D level, Fourteen infants $(28 \%)$ were finally diagnosed as CMA. No test or parameter at baseline differentiate infants with and without CMA. Only one infant had positive atopy patch test, none had positive serum IgE 
and, surprisingly, permeability test was higher in non-CMA infants. In the group with CMA, elimination diet significantly improved GERD symptoms, esophageal clearance and baseline, indirect parameters of esophageal function and mucosal integrity [29].

To quantify the evolution of symptoms and the benefit to the individual patient of any diet or therapeutic intervention, a follow-up visit after 2 weeks should be planned and the evaluation of a daily diary reporting pattern of stools, duration of inconsolable crying, episodes of regurgitation, feeding and sleeping disturbs, CoMiSS and I-GERQ-R scores would be useful to track symptoms.

A simplified stepwise approach and action plan for infants with persistent regurgitation, vomiting and crying is shown in Figure 1.

A correct diagnostic classification is essential to avoid the possible mislabel of "disease" in a "functional" condition or the use of protracted or unnecessary diets [31] or drugs with possible adverse effects [84].

\section{The Third Wheel: Eosinophilic Esophagitis}

The first report of eosinophilic esophagitis (EoE) dates back 1995 [86]. Ten children (median age 5 years, range 8 months-12.5 years), with intractable symptoms attributed to GERD but not responsive to reflux treatment (included Nissen fundoplication in 6 of them), showed improvement (in two patients) or complete resolution (in 8 children) of clinical picture when fed with an amino acid based formula (for at least 6 weeks) and relapsed on challenge. The striking feature was the detection of a high eosinophilic infiltrate (median, 41; range, 15-100) in the esophagus in all cases, with mucosal healing on elemental diet (median, 0.5; range, 0-22) [86]. Since then, EoE has been increasingly recognized at all ages throughout the world. While in children and adolescents dysphagia, bolus impaction, vomiting, epigastric pain and selective feeding can be indicators of EoE, in infants symptoms include regurgitation, vomiting, feeding difficulties, crying, fussiness and poor growth $[86,87]$.

The overlap with CMA not only results from the clinical picture but also from the presence of positive family history of allergy, atopic manifestations and positive allergy tests in about $50 \%$ of EoE cases, with a response to a CM and/or other food elimination diet in $70-90 \%$ of patients [88].

The similarity with GERD is mainly based on the possible reduction of symptoms, acid exposure and esophageal inflammation with PPI [82] (Figure 2). Furthermore, patients with EoE may present a pathological $\mathrm{pH}$-impedance, esophageal dysfunction and stricture [82].

Moreover, CMA, GERD and EoE can all occur with acute, chronic and relapsing manifestations which are difficult to differentiate between the three conditions, particularly in infants and young children $[18,26,87,88]$.

The endoscopic finding of EoE is very variable and can range from normal appearance (particularly in infants) [86] to one or more of the following suggestive but not specific features: food bolus impaction, edema, linear furrows, friability, erosions, ulcerations, concentric rings (up to appearance of trachealization of the lumen), whitish exudates and stricture. The detection of a marked eosinophilic infiltration ( $>15$ by high magnification field, HPF) in at least one esophageal biopsy is the diagnostic hallmark of EoE [87].

The exact prevalence of EoE in both breast- and formula-fed infants [61] is difficult to determine because few infants have endoscopy and esophageal biopsies before been attempted CM free diet or PPI treatment. Moreover, pediatric EoE case series did not provide a subgroup analysis of infants [89] and one large report on infant esophagitis did not detail eosinophilic infiltration [56]. Noteworthy, several early-life factors, including maternal fever, preterm labor, cesarean delivery, esophageal atresia, antibiotic or acid suppressant use in the first months of life, dysbiosis, other atopic conditions and celiac disease have been associated with risk of pediatric EoE [90,91]. 


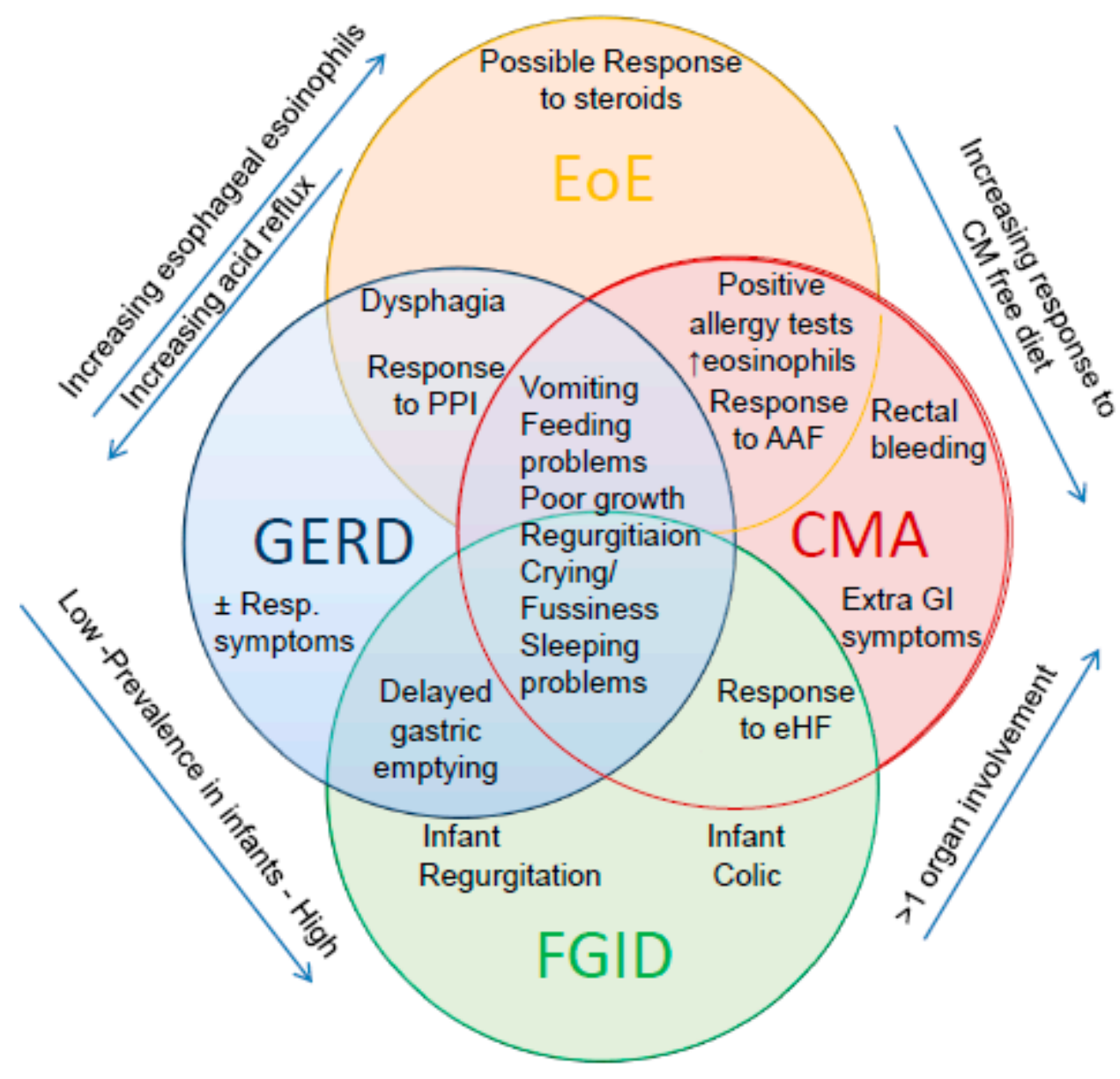

Figure 2. The challenging clinical overlap among Functional Gastrointestinal Disorder (FGID), GERD, CMA and eosinophilic esophagitis (EoE) in infants (modified from Nielsen 2006 [18].

The natural history and disease progression of EoE, as well as of CMA and GERD, are not yet well defined because pathogenesis is complex and not fully understood [92]. Therapeutic options for EoE include, as single or sequential intervention: proton pump inhibitors, elimination or elementary diet to avoid allergenic exposure and related inflammation [88]; topical steroids for anti-inflammatory effects; endoscopic dilations for severe stenosis. Immunosuppressive agents and immunomodulators have also been proposed, especially in non-responders adolescents and adults but need further validation [92]. To date, there is no specific, universally accepted and effective treatment for EoE in all patients; consequently, in clinical practice, the therapeutic approach is often individually adapted, especially as regards the choice between dietary or steroid treatment $[82,87,92]$. On the contrary, in infants the first and, in almost all cases, the only treatment needed for EoE is CM free diet with recommended amino acid formula [31,86,87]. In a recent review of ten studies, enrolling 462 EoE patients (mean age 6.7 years, range, 4 months-20 years), elemental diet resulted in clinical and histological remission (defined as $\leq 10$ eosinophils/hpf) in $75-100 \%$ of children [89]. Despite diagnostic difficulties an early recognition of EoE is important to resolve or reduce clinical manifestations and possible long term esophageal complications.

\section{Conclusions}

Persistent regurgitation, vomiting, distress and crying are common symptoms in the first year of life, often coexist in the same patient and can be related to CMA, functional gastrointestinal disorders, GERD, eosinophilic esophagitis and also other different diseases. The real prevalence and the mechanisms underlying the association between CMA and 
GERD are not yet fully clarified. The lack of an accurate test for non-IgE mediated CMA and for GERD determines the difficulty of a correct diagnostic classification and carries the risk of both delayed recognition and overtreatment. After exclusion of alarm signs for other organic pathologies, a stepwise approach, starting from behavioral and nutritional intervention moving to selected investigations in infants with persistent symptoms could better select infants to start diet and drugs. Because the response to elimination diet, alginate or acid inhibitors may be due to the natural evolution of underlying condition or other than immune or reflux-related mechanisms, periodic reassessment of the patient is essential to avoid misdiagnosis and excessive use of the proposed intervention.

Author Contributions: S.S., M.A. and Y.V. contributed to conception and design of the review, interpretation of data, drafting the article and final approval of the version to be published; M.E.B., E.D., L.N., L.P. contributed to interpretation of data, drafting the article and final approval of the version to be published. All authors have read and agreed to the published version of the manuscript.

Funding: This review received no external funding.

Institutional Review Board Statement: Not applicable.

Informed Consent Statement: Not applicable.

Conflicts of Interest: S.S. has participated as advisory board member, and/or consultant, and/or speaker for Bioproject, Danone, D.M.G., Mellin, Nestlé, Novalac; M.E.B. has participated as consultant for Aurora Biofarma, Y.V. has participated as a clinical investigator, and/or advisory board member, and/or consultant, and/or speaker for Abbott Nutrition, Biocodex, Biogaia, CHR Hansen, Danone, Nestle Health Science, Nestle Nutrition Institute, Nutricia, Mead Johnson Nutrition, United Pharmaceuticals, Wyeth. All the above manufacturers and companies have had no input or involvement in any aspect of this study. The other authors have no conflict of interest to disclose.

\begin{tabular}{|c|c|}
\hline \multicolumn{2}{|c|}{ Abbreviations } \\
\hline AAF & Amino acid-based formula \\
\hline $\mathrm{CM}$ & cow's milk \\
\hline CMA & cow's milk protein allergy \\
\hline CoMiss & cow's milk related symptom score \\
\hline EoE & eosinophilic esophagitis \\
\hline FGIDs & functional gastrointestinal disorders \\
\hline GER & gastroesophageal reflux \\
\hline GERD & gastroesophageal reflux disease \\
\hline I-GERQ-R & revised infant GER questionnaire \\
\hline PPI & proton pump inhibitors \\
\hline
\end{tabular}

\section{References}

1. Salvatore, S.; Vandenplas, Y. Gastroesophageal reflux and cow milk allergy: Is there a link? Pediatrics 2002, 110, 972-984. [CrossRef] [PubMed]

2. Nwaru, B.I.; Hickstein, L.; Panesar, S.S.; Roberts, G.; Muraro, A.; Sheikh, A. EAACI Food Allergy and Anaphylaxis Guidelines Group Prevalence of common food allergies in Europe: A systematic review and meta-analysis. Allergy 2014, 69, $992-1007$. [CrossRef] [PubMed]

3. Vandenplas, Y.; Abkari, A.; Bellaiche, M.; Benninga, M.A.; Chouraqui, J.P.; Çokuðrap, F.; Harb, T.; Hegar, B.; Lifschitz, C.H.; Ludwig, T.; et al. Prevalence and Health Outcomes of Functional Gastrointestinal Symptoms in Infants From Birth to 12 Months of Age. J. Pediatr. Gastroenterol. Nutr. 2015, 61, 531-537. [CrossRef] [PubMed]

4. Vandenplas, Y.; Benninga, M.; Broekaert, I.; Falconer, J.; Gottrand, F.; Guarino, A.; Lifschitz, C.; Lionetti, P.; Orel, R.; Papadopoulou, A.; et al. Functional gastro-intestinal disorder algorithms focus on early recognition, parental reassurance and nutritional strategies. Acta Paediatr. 2015, 105, 244-252. [CrossRef]

5. Forget, P.; Arends, J.W. Cow's milk protein allergy and gastro-oesophageal reflux. Eur. J. Pediatr. 1985, 144, 298-300. [CrossRef]

6. McLain, B.I.; Cameron, D.J.S.; Barnes, G.L. Is cow's milk protein intolerance a cause of gastro-oesophageal reflux in infancy? J. Paediatr. Child. Health 1994, 30, 316-318. [CrossRef]

7. Cavataio, F.; Iacono, G.; Montalto, G.; Soresi, M.; Tumminello, M.; Campagna, P.; Notarbartolo, A.; Carroccio, A. Gastroesophageal reflux associated with cow's milk allergy in infants, which diagnostic examinations are useful? Am. J. Gastroenterol. 1996, 91, 1215-1220. 
8. Cavataio, F.; Iacono, G.; Montalto, G.; Soresi, M.; Tumminello, M.; Carroccio, A. Clinical and pH-metric characteristics of gastro-oesophageal reflux secondary to cows' milk protein allergy. Arch. Dis. Child. 1996, 75, 51-56. [CrossRef]

9. Iacono, G.; Carroccio, A.; Cavataio, F.; Montalto, G.; Kazmierska, I.; Lorello, D.; Soresi, M.; Notarbartolo, A. Gastroesophageal reflux and cow's milk allergy in infants, a prospective study. J. Allergy Clin. Immunol. 1996, 97, 822-827.

10. Milocco, C.; Torre, G.; Ventura, A. Gastro-oesophageal reflux and cows' milk protein allergy. Arch. Dis. Child. 1997, 77, 183. [CrossRef]

11. Staiano, A.; Troncone, R.; Simeone, D.; Mayer, M.; Finelli, E.; Cella, A.; Auricchio, S. Differentiation of cows' milk intolerance and gastro-oesophageal reflux. Arch. Dis. Child. 1995, 73, 439-442. [CrossRef] [PubMed]

12. Garzi, A.; Messina, M.; Frati, F.; Carfagna, L.; Zagordo, L.; Belcastro, M.; Parmiani, S.; Sensi, L.; Marcucci, F. An extensively hydrolysed cow's milk formula im-proves clinical symptoms of gastroesophageal reflux and reduces the gastric emptying time in infants. Allergol. Immunopathol. 2002, 30, 36-41.

13. Farahmand, F.; Najafi, M.; Ataee, P.; Modarresi, V.; Shahraki, T.; Rezaei, N. Cow's milk allergy among children with gastroesophageal reflux disease. Gut Liver. 2011, 5, 298-301. [CrossRef] [PubMed]

14. Hill, D.J.; Heine, R.G.; Cameron, D.J.; Cairo-Smith, A.G.; Chow, C.W.; Francis, D.E.; Hosking, C.S. Role of food protein intolerance in infants with persistent distress attributed to reflux esophagitis. J. Pediatr. 2000, 136, 641-647. [CrossRef] [PubMed]

15. Heine, R.G. Gastroesophageal reflux disease, colic and constipation in infants with food allergy. Curr. Opin. Allergy Clin. Immunol. 2006, 6, 220-225. [CrossRef] [PubMed]

16. Heine, R.G.; Jordan, B.; Lubitz, L.; Meehan, M.; Catto-Smith, A.G. Clinical predictors of pathological gastro-oesophageal reflux in infants with persistent distress. J. Paediatr. Child. Health 2006, 42, 134-139. [CrossRef] [PubMed]

17. Nielsen, R.G.; Bindslev-Jensen, C.; Kruse-Andersen, S.; Husby, S. Severe Gastroesophageal Reflux Disease and Cow Milk Hypersensitivity in Infants and Children: Disease Association and Evaluation of a New Challenge Procedure. J. Pediatr. Gastroenterol. Nutr. 2004, 39, 383-391. [CrossRef]

18. Nielsen, R.G.; Fenger, C.; Bindslev-Jensen, C.; Husby, S. Eosinophilia in the upper gastrointestinal tract is not a characteristic fea-ture in cow's milk sensitive gastro-oesophageal reflux disease Measurement by two methodologies. J. Clin. Pathol. 2006, 59, 89-94. [CrossRef]

19. Semeniuk, J.; Kaczmarski, M. 24-hour esophageal pH monitoring in children with pathological acid gastroesophageal reflux: Primary and secondary to food allergy. Part, I. Intraesophageal $\mathrm{pH}$ values in distal channel; preliminary study and control studies-after 1, 2, 4 and 9 years of clinical observation as well as dietary and pharmacological treatment. Adv. Med. Sci. 2007, 52, 199-205.

20. Semeniuk, J.; Kaczmarski, M.; Uścinowicz, M. Manometric study of lower esophageal sphincter in children with primary acid gastroesophageal reflux and acid gastroesophageal reflux secondary to food allergy. Adv. Med. Sci. 2008, 53. [CrossRef]

21. Ravelli, A.M.; Tobanelli, P.; Volpi, S.; Ugazio, A.G. Vomiting and gastric motility in infants with cow's milk allergy. J. Pediatr. Gastroenterol. Nutr. 2001, 32, 59-64. [CrossRef] [PubMed]

22. Borrelli, O.; Mancini, V.; Thapar, N.; Giorgio, V.; Elawad, M.; Hill, S.; Shah, N.; Lindley, K.J. Cow's Milk Challenge Increases Weakly Acidic Reflux in Children with Cow's Milk Allergy and Gastroesophageal Reflux Disease. J. Pediatr. 2012, 161, 476-481.e1. [CrossRef] [PubMed]

23. Ferreira, C.T.; de Carvalho, E.; Sdepanian, V.L.; Morais, M.B.; Vieira, M.C.; Silva, L.R. Gastroesophageal reflux disease, exaggerations, evidence and clinical practice. J. Pediatr. 2014, 90, 105-118. [CrossRef] [PubMed]

24. Vandenplas, Y.; De Greef, E.; ALLAR Study Group. Extensive protein hydrolysate formula effectively reduces regurgitation in infants with positive and negative challenge tests for cow's milk allergy. Acta Paediatr. 2014, 103, e243-e250. [CrossRef]

25. Nocerino, R.; Pezzella, V.; Cosenza, L.; Amoroso, A.; Di Scala, C.; Amato, F.; Iacono, G.; Canani, R.B. The Controversial Role of Food Allergy in Infantile Colic: Evidence and Clinical Management. Nutrients 2015, 7, 2015-2025. [CrossRef]

26. Yukselen, A.; Celtik, C. Food allergy in children with refractory gastroesophageal reflux disease. Pediatr. Int. 2015, 58, 254-258. [CrossRef]

27. Pensabene, L.; Salvatore, S.; D’Auria, E.; Parisi, F.; Concolino, D.; Borrelli, O.; Thapar, N.; Staiano, A.; Vandenplas, Y.; Saps, M. Cow's Milk Protein Allergy in Infancy: A Risk Factor for Functional Gastrointestinal Disorders in Children? Nutrients 2018, 10, 1716. [CrossRef]

28. D'Auria, E.; Salvatore, S.; Pozzi, E.; Mantegazza, C.; Sartorio, M.U.A.; Pensabene, L.; Baldassarre, M.E.; Agosti, M.; Vandenplas, Y.; Zuccotti, G.V. Cow's Milk Allergy: Immunomodulation by Dietary Intervention. Nutrients 2019, 11, 1399. [CrossRef]

29. Omari, T.; Tobin, J.M.; McCall, L. Characterization of Upper Gastrointestinal Motility in Infants with Persistent Distress and Non-IgE-mediated Cow's Milk Protein Allergy. J. Pediatr. Gastroenterol. Nutr. 2020, 70, 489-496. [CrossRef]

30. Koletzko, S.; Niggemann, B.; Arato, A.; Dias, J.A.; Heuschkel, R.; Husby, S.; Mearin, M.L.; Papadopoulou, A.; Ruemmele, F.M.; Staiano, A.; et al. Diagnostic approach and management of cow's-milk protein allergy in infants and children, ESPGHAN gastrointestinal committee practical guidelines. J. Pediatr. Gastroenterol. Nutr. 2012, 55, 221-229. [CrossRef]

31. Muraro, A.; Werfel, T.; Hoffmann-Sommergruber, K.A.; Roberts, G.; Beyer, K.; Bindslev-Jensen, C.; Cardona, V.; Dubois, A.; Dutoit, G.; Eigenmann, P.; et al. EAACI Food Allergy and Anaphylaxis Guidelines: Diagnosis and management of food allergy. Allergy 2014, 69, 1008-1025. [CrossRef] [PubMed]

32. Luyt, D.; Ball, H.; Makwana, N.; Green, M.R.; Bravin, K.; Nasser, S.M.; Clark, A. BSACI guideline for the diagnosis and management of cow's milk allergy. Clin. Exp. Allergy 2014, 44, 642-672. [CrossRef] [PubMed] 
33. Fiocchi, A.G.; Dahda, L.; Dupont, C.; Campoy, C.; Fierro, V.; Nieto, A. Cow's milk allergy: Towards an update of DRACMA guidelines. World Allergy Organ. J. 2016, 9, 35. [CrossRef] [PubMed]

34. Rosen, R.; Vandenplas, Y.; Singendonk, M.; Cabana, M.; Di Lorenzo, C.; Gottrand, F.; Gupta, S.; Langendam, M.; Staiano, A.; Thapar, N.; et al. Pediatric Gastroesophageal Reflux Clinical Practice Guidelines, Joint Recommendations of the North American Society for Pediatric Gastroenterology, Hepatology, and Nutrition (NASPGHAN) and the European Society for Pediatric Gastroenterology, Hepatology, and Nutrition (ESPGHAN). J. Pediatr. Gastroenterol. Nutr. 2018, 66, 516-554. [PubMed]

35. Quitadamo, P.; Tambucci, R.; Mancini, V.; Cristofori, F.; Baldassarre, M.; Pensabene, L.; Francavilla, R.; Di Nardo, G.; Caldaro, T.; Rossi, P.; et al. Esophageal pH-impedance monitoring in children: Position paper on indications, methodology and interpretation by the SIGENP working group. Dig. Liver Dis. 2019, 51, 1522-1536. [CrossRef] [PubMed]

36. Sicherer, S.H.; Sampson, H.A. Food allergy, A review and update on epidemiology, pathogenesis, diagnosis, prevention, and management. J. Allergy Clin. Immunol. 2018, 141, 41-58. [CrossRef]

37. Schäppi, M.G.; Borrelli, O.; Knafelz, D.; Williams, S.; Smith, V.V.; Milla, P.J.; Lindley, K.J. Mast Cell-Nerve Interactions in Children with Functional Dyspepsia. J. Pediatr. Gastroenterol. Nutr. 2008, 47, 472-480. [CrossRef]

38. Shamir, R.; St James-Roberts, I.; Di Lorenzo, C.; Burns, A.J.; Thapar, N.; Indrio, F.; Riezzo, G.; Raimondi, F.; Di Mauro, A.; Francavilla, R.; et al. Infant crying, colic, and gastrointestinal discomfort in early childhood, a review of the evidence and most plausible mechanisms. J. Pediatr. Gastroenterol. Nutr. 2013, 57, S1.

39. Salvatore, S.; Abkari, A.; Cai, W.; Catto-Smith, A.; Cruchet, S.; Gottrand, F.; Hegar, B.; Lifschitz, C.; Ludwig, T.; Shah, N.; et al. Review shows that parental reassurance and nutritional advice help to optimise the management of functional gastrointestinal disorders in infants. Acta Paediatr. 2018, 107, 1512-1520. [CrossRef]

40. Yadlapati, R.; Kahrilas, P.J. The "dangers" of chronic proton pump inhibitor use. J. Allergy Clin. Immunol. 2018, 141, 79-81. [CrossRef]

41. Levy, E.J.; Vandenplas, Y. Proton pump inhibitors, microbiota and micronutrients. Acta Paediatr. 2020, 109, 1531-1538. [CrossRef] [PubMed]

42. Benninga, M.A.; Nurko, S.; Faure, C.; Hyman, P.E.; Roberts, I.S.J.; Schechter, N.L. Childhood Functional Gastrointestinal Disorders: Neonate/Toddler. Gastroenterology 2016, 150, 1443-1455.e2. [CrossRef]

43. Wolke, D.; Bilgin, A.; Samara, M. Systematic review and meta-analysis, fussing and crying durations and prevalence of colic in infants. J. Pediatr. 2017, 185, 55-61. [CrossRef] [PubMed]

44. Bellaiche, M.; Oozeer, R.; Gerardi-Temporel, G.; Faure, C.; Vandenplas, Y. Multiple functional gastrointestinal disorders are frequent in formula-fed infants and decrease their quality of life. Acta Paediatr. 2018, 107, 1276-1282. [CrossRef]

45. Salvatore, S.; Baldassarre, M.E.; Di Mauro, A.; Laforgia, N.; Tafuri, S.; Bianchi, F.P.; Dattoli, E.; Morando, L.; Pensabene, L.; Meneghin, F.; et al. Neonatal Antibiotics and Prematurity Are Associated with an Increased Risk of Functional Gastrointestinal Disorders in the First Year of Life. J. Pediatr. 2019, 212, 44-51. [CrossRef] [PubMed]

46. Baldassarre, M.E.; Di Mauro, A.; Salvatore, S.; Tafuri, S.; Bianchi, F.P.; Dattoli, E.; Morando, L.; Pensabene, L.; Meneghin, F.; DiLillo, D.; et al. Birth Weight and the Development of Functional Gastrointestinal Disorders in Infants. Pediatr. Gastroenterol. Hepatol. Nutr. 2020, 23, 366-376. [CrossRef]

47. Salvatore, S.; Barberi, S.; Borrelli, O.; Castellazzi, A.; Di Mauro, D.; Di Mauro, G.; Doria, M.; Francavilla, R.; Landi, M.; Martelli, A.; et al. Pharmacological interventions on early functional gastrointestinal disorders. Ital. J. Pediatr. 2016, 42, 1-8. [CrossRef] [PubMed]

48. Nelson, S.P.; Chen, E.H.; Syniar, G.M. Prevalence of symptoms of gastroesophageal reflux in infancy. Arch. Pediatr. Adolesc. Med. 1997, 151, 569-572. [CrossRef] [PubMed]

49. Hegar, B.; Dewanti, N.R.; Kadim, M.; Alatas, S.; Firmansyah, A.; Vandenplas, Y. Natural evolution of regurgitation in healthy infants. Acta Paediatr. 2009, 98, 1189-1193. [CrossRef] [PubMed]

50. Salvatore, S.; Vandenplas, Y. Epidemiology. In Gastroesophageal Reflux in Children; Vandenplas, Y., Ed.; Springer: Cham, Switzerland, 2017. [CrossRef]

51. Salvatore, S.; Hauser, B.; Vandemaele, K.; Novario, R.; Vandenplas, Y. Gastroesophageal reflux disease in infants, how much is predictable with questionnaires, pH-metry, endoscopy and histology? J. Pediatr. Gastroenterol. Nutr. 2005, 40, 210-215. [CrossRef]

52. Orenstein, S.R.; Hassall, E.; Furmaga-Jablonska, W.; Atkinson, S.; Raanan, M. Multicenter, double-blind, randomized, placebocontrolled trial assessing the efficacy and safety of proton pump inhibitor lansoprazole in infants with symptoms of gastroesophageal reflux disease. J. Pediatr. 2009, 154, 514-520. [CrossRef] [PubMed]

53. Salvatore, S.; Arrigo, S.; Luini, C.; Vandenplas, Y. Esophageal Impedance in Children: Symptom-Based Results. J. Pediatr. 2010, 157, 949-954.e2. [CrossRef] [PubMed]

54. Vandenplas, Y.; Goyvaerts, H.; Helven, R.; Sacre, L. Gastroesophageal reflux, as measured by 24-hour pH monitoring, in 509 healthy infants screened for risk of sudden infant death syndrome. Pediatrics 1991, 88, 834-840. [PubMed]

55. Gilger, M.A.; El-Serag, H.B.; Gold, B.D.; Dietrich, C.L.; Tsou, V.; McDuffie, A.; Shub, M.D. Prevalence of Endoscopic Findings of Erosive Esophagitis in Children: A Population-based Study. J. Pediatr. Gastroenterol. Nutr. 2008, 47, 141-146. [CrossRef] [PubMed]

56. Volonaki, E.; Sebire, N.J.; Borrelli, O.; Lindley, K.J.; Elawad, M.; Thapar, N.; Shah, N. Gastrointestinal endoscopy and mucosal biopsy in the first year of life, indications and outcome. J. Pediatr. Gastroenterol. Nutr. 2012, 55, 62-65. [CrossRef] [PubMed]

57. Salvatore, S.; Ripepi, A.; Huysentruyt, K.; Van De Maele, K.; Nosetti, L.; Agosti, M.; Salvatoni, A.; Vandenplas, Y. The Effect of Alginate in Gastroesophageal Reflux in Infants. Pediatr. Drugs 2018, 20, 575-583. [CrossRef] [PubMed] 
58. Salvatore, S.; Pagliarin, F.; Huysentruyt, K.; Bosco, A.; Fumagalli, L.; Van De Maele, K.; Agosti, M.; Vandenplas, Y. Distress in Infants and Young Children, Don't Blame Acid Reflux. J. Pediatr. Gastroenterol. Nutr. 2020, 71, 465-469. [CrossRef]

59. Schoemaker, A.A.; Sprikkelman, A.B.; Grimshaw, K.E.; Roberts, G.; Grabenhenrich, L.; Rosenfeld, L.; Siegert, S.; Dubakiene, R.; Rudzeviciene, O.; Reche, M.; et al. Incidence and natural history of challenge-proven cow's milk allergy in European children-EuroPrevall birth cohort. Allergy 2015, 70, 963-972. [CrossRef] [PubMed]

60. Saarinen, K.M.; Juntunen-Backman, K.; Järvenpää, A.-L.; Klemetti, P.; Kuitunen, P.; Lope, L.; Renlund, M.; Siivola, M.; Vaarala, O.; Savilahti, E. Breast-Feeding and the Development of Cows' Milk Protein Allergy. Adv. Exp. Med. Biol. 2000, 478, 121-130. [CrossRef]

61. Meyer, R.; Chebar Lozinsky, A.; Fleischer, D.M.; Vieira, M.C.; Du Toit, G.; Vandenplas, Y.; Dupont, C.; Knibb, R.; Uysal, P.; Cavkaytar, O.; et al. Diagnosis and management of Non-IgE gastrointestinal allergies in breastfed infants-An EAACI Position Paper. Allergy 2020, 75, 14-32. [CrossRef]

62. Hait, E.J.; McDonald, D.R. Impact of Gastroesophageal Reflux Disease on Mucosal Immunity and Atopic Disorders. Clin. Rev. Allergy Immunol. 2019, 57, 213-225. [CrossRef] [PubMed]

63. Nowak-Wegrzyn, A.; Chehade, M.; Groetch, M.E.; Spergel, J.M.; Wood, R.A.; Allen, K.; Atkins, D.; Bahna, S.; Barad, A.V.; Berin, C.; et al. International consensus guidelines for the diagnosis and management of food protein-induced enterocolitis syndrome, executive summary-Workgroup Report of the Adverse Reactions to Foods Committee, American Academy of Allergy, Asthma \& Immunology. J. Allergy Clin. Immunol. 2017, 139, 1111-1126. [PubMed]

64. Labrosse, R.; Graham, F.; Caubert, J.C. Non-IgE-mediated gastrointestinal food allergies in children, an update. Nutrients 2020, 12, 2086. [CrossRef] [PubMed]

65. Gonzalez Ayerbe, J.I.; Hauser, B.; Salvatore, S.; Vandenplas, Y. Diagnosis and Management of Gastroesophageal Reflux Disease in Infants and Children, from Guidelines to Clinical Practice. Pediatr. Gastroenterol. Hepatol. Nutr. 2019, 22, 107-121. [CrossRef] [PubMed]

66. Salvatore, S.; Savino, F.; Singendonk, M.; Tabbers, M.; Benninga, M.A.; Staiano, A.; Vandenplas, Y. Thickened formula, what to know. Nutrition 2018, 49, 51-56. [CrossRef]

67. Baldassarre, M.E.; Di Mauro, A.; Pignatelli, M.C.; Fanelli, M.; Salvatore, S.; Di Nardo, G.; Chiaro, A.; Pensabene, L.; Laforgia, N. Magnesium Alginate in Gastro-Esophageal Reflux: A Randomized Multicenter Cross-Over Study in Infants. Int. J. Environ. Res. Public Health 2019, 17, 83. [CrossRef]

68. Vandenplas, Y. Prevention and Management of Cow's Milk Allergy in Non-Exclusively Breastfed Infants. Nutrients 2017, 9, 731. [CrossRef]

69. Verduci, E.; D’Elios, S.; Cerrato, L.; Comberiati, P.; Calvani, M.; Palazzo, S.; Martelli, A.; Landi, M.; Trikamjee, T.; Peroni, D. Cow's Milk Substitutes for Children: Nutritional Aspects of Milk from Different Mammalian Species, Special Formula and Plant-Based Beverages. Nutrients 2019, 11, 1739. [CrossRef]

70. Salvatore, S.; Vandenplas, Y. Hydrolyzed Proteins in Allergy. Nestle Nutr. Inst. Workshop Ser. 2016, 86, 11-27.

71. Vandenplas, Y.; Dupont, C.; Eigenmann, P.; Host, A.; Kuitunen, M.; Ribes-Koninckx, C.; Shah, N.; Shamir, R.; Staiano, A.; Szajewska, H.; et al. A workshop report on the development of the Cow's Milk-related Symptom Score awareness tool for young children. Acta Paediatr. 2015, 104, 334-339. [CrossRef]

72. Vandenplas, Y.; Steenhout, P.; Järvi, A.; Garreau, A.-S.; Mukherjee, R. Pooled Analysis of the Cow's Milk-related-Symptom-Score (CoMiSSTM) as a Predictor for Cow's Milk Related Symptoms. Pediatr. Gastroenterol. Hepatol. Nutr. 2017, 20, 22. [CrossRef] [PubMed]

73. Salvatore, S.; Bertoni, E.; Bogni, F.; Bonaita, V.; Armano, C.; Moretti, A.; Baù, M.; Luini, C.; D'Auria, E.; Marinoni, M.; et al. Testing the Cow's Milk-Related Symptom Score (CoMiSSTM) for the Response to a Cow's Milk-Free Diet in Infants, A Prospective Study. Nutrients. 2019, 11, 2402. [CrossRef]

74. Vandenplas, Y.; Salvatore, S.; Ribes-Koninckx, C.; Carvajal, E.; Szajewska, H.; Huysentruyt, K. The Cow Milk Symptom Score (CoMiSSTM) in presumed healthy infants. PLoS ONE 2018, 13, e0200603. [CrossRef] [PubMed]

75. Lucassen, P. Colic in infants. BMJ Clin. Evid. 2010, 2010, 309.

76. Iacovou, M.; Ralston, R.A.; Muir, J.; Walker, K.Z.; Truby, H. Dietary management of infantile colic, a systematic review. Matern. Child Health J. 2012, 16, 1319-1331. [CrossRef] [PubMed]

77. Gordon, M.; Biagioli, E.; Sorrenti, M.; Lingua, C.; Moja, L.; Banks, S.S.; Ceratto, S.; Savino, F. Dietary modification for infantile colic. Cochrane Database Syst. Rev. 2018, 10, CD011029. [CrossRef] [PubMed]

78. Taubman, B. Parental counseling compared with elimination of cow's milk or soy milk protein for the treatment of infant colic syndrome, a randomized trial. Pediatrics 1988, 81, 756-761.

79. Savino, F.; Palumeri, E.; Castagno, E.; Cresi, F.; Dalmasso, P.; Cavallo, F.; Oggero, R. Reduction of crying episodes owing to infantile colic: A randomized controlled study on the efficacy of a new infant formula. Eur. J. Clin. Nutr. 2006, 60, 1304-1310. [CrossRef]

80. Orenstein, S.R. Symptoms and reflux in infants, Infant Gastroesophageal Reflux Questionnaire Revised (I-GERQ-R)—Utility for symptom tracking and diagnosis. Curr. Gastroenterol. Rep. 2010, 12, 431-436. [CrossRef]

81. Gieruszczak-Białek, D.; Konarska, Z.; Skórka, A.; Vandenplas, Y.; Szajewska, H. No Effect of Proton Pump Inhibitors on Crying and Irritability in Infants: Systematic Review of Randomized Controlled Trials. J. Pediatr. 2015, 166, 767-770.e3. [CrossRef] 
82. Lucendo, A.J.; Arias, Á.; Molina-Infante, J. Efficacy of Proton Pump Inhibitor Drugs for Inducing Clinical and Histologic Remission in Patients With Symptomatic Esophageal Eosinophilia, A Systematic Review and Meta-Analysis. Clin. Gastroenterol. Hepatol. 2016, 14, 13-22. [CrossRef] [PubMed]

83. National Institute for Health and Care Excellence (NICE). Gastro-Oesophageal Reflux Disease, Recognition, Diagnosis and Management in Children and Young People. (Clinical Guideline 193). 2015. Available online: http, / / www.nice.org.uk/guidance/ NG1 (accessed on 30 April 2015).

84. Levy, E.I.; Salvatore, S.; Vandenplas, Y.; De Winter, J.P. Prescription of acid inhibitors in infants: An addiction hard to break. Eur. J. Pediatr. 2020, 179, 1957-1961. [CrossRef]

85. Mantegazza, C.; Mallardo, S.; Rossano, M.; Meneghin, F.; Ricci, M.; Rossi, P.; Capra, G.; Latorre, P.; Schindler, A.; Isoldi, S.; et al. Laryngeal signs and $\mathrm{pH}$-multichannel intraluminal impedance in infants and children, The missing ring, LPR and MII-pH in children. Dig. Liver Dis. 2020, 52, 1011-1016. [CrossRef] [PubMed]

86. Kelly, K.J.; Lazenby, A.J.; Rowe, P.C.; Yardley, J.H.; Perman, J.A.; Sampson, H.A. Eosinophilic esophagitis attributed to gastroesophageal reflux: Improvement with an amino acid-based formula. Gastroenterology 1995, 109, 1503-1512. [CrossRef]

87. Papadopoulou, A.; Koletzko, S.; Heuschkel, R.; Dias, J.; Allen, K.; Murch, S.; Chong, S.; Gottrand, F.; Husby, S.; Lionetti, P.; et al. Management Guidelines of Eosinophilic Esophagitis in Childhood. J. Pediatr. Gastroenterol. Nutr. 2014, 58, 107-118. [CrossRef] [PubMed]

88. Venter, C.; Fleischer, D.M. Diets for diagnosis and management of food allergy, The role of the dietitian in eosinophilic esophagitis in adults and children. Ann. Allergy Asthma Immunol. 2016, 117, 468-471. [CrossRef]

89. Atwal, K.; Hubbard, G.P.; Venter, C.; Stratton, R.J. The use of amino acid-based nutritional feeds is effective in the dietary management of pediatric eosinophilic oesophagitis. Immunity Inflamm. Dis. 2019, 7, 292-303. [CrossRef] [PubMed]

90. Jensen, E.T.; Kuhl, J.T.; Martin, L.J.; Rothenberg, M.E.; Dellon, E.S. Prenatal, intrapartum, and postnatal factors are associated with pediatric eosinophilic esophagitis. J. Allergy Clin. Immunol. 2018, 141, 214-222. [CrossRef]

91. Votto, M.; Marseglia, G.L.; De Filippo, M.; Brambilla, I.; Caimmi, S.M.E.; Licari, A. Early Life Risk Factors in Pediatric EoE: Could We Prevent This Modern Disease? Front. Pediatr. 2020, 8, 263. [CrossRef]

92. Cheng, E. Translating New Developments in Eosinophilic Esophagitis Pathogenesis into Clinical Practice. Curr Treat Options Gastroenterol. 2015, 13, 30-46. [CrossRef] 